https://helda.helsinki.fi

\title{
Mandeville, Bernard
}

\section{Tolonen, Mikko}

Springer

2020

Tolonen , M , Simonazzi , M \& Branchi , A 2020 , Mandeville, Bernard . in D Jalobeanu \& C T Wolfe (eds), Encyclopedia of Early Modern Philosophy and the Sciences. Springer , Cham . https://doi.org/10.1007/978-3-319-20791-9_498-1

http://hdl.handle.net/10138/314393

https://doi.org/10.1007/978-3-319-20791-9_498-1

cc_by

draft

Downloaded from Helda, University of Helsinki institutional repository.

This is an electronic reprint of the original article.

This reprint may differ from the original in pagination and typographic detail.

Please cite the original version. 


\begin{tabular}{|c|c|c|}
\hline Chapter Title & \multicolumn{2}{|l|}{ Mandeville, Bernard } \\
\hline Copyright Year & \multicolumn{2}{|l|}{2020} \\
\hline Copyright Holder & \multicolumn{2}{|c|}{ Springer Nature Switzerland AG } \\
\hline \multirow[t]{9}{*}{ Corresponding Author } & Family Name & Tolonen \\
\hline & Particle & \\
\hline & Given Name & Mikko \\
\hline & Suffix & \\
\hline & Division/Department & Department of Digital Humanities \\
\hline & Organization/University & University of Helsinki \\
\hline & City & Helsinki \\
\hline & Country & Finland \\
\hline & Email & mikko.tolonen@helsinki.fi \\
\hline \multirow[t]{9}{*}{ Author } & Family Name & Simonazzi \\
\hline & Particle & \\
\hline & Given Name & Mauro \\
\hline & Suffix & \\
\hline & Division/Department & Department of Philosophy \\
\hline & Organization/University & University of Milan \\
\hline & City & Milan \\
\hline & Country & Italy \\
\hline & Email & mauro.simonazzi@unimi.it \\
\hline \multirow[t]{9}{*}{ Author } & Family Name & Branchi \\
\hline & Particle & \\
\hline & Given Name & Andrea \\
\hline & Suffix & \\
\hline & Division/Department & IR Department \\
\hline & Organization/University & American University of Rome \\
\hline & City & Rome \\
\hline & Country & Italy \\
\hline & Email & ab509@columbia.edu / \\
\hline $\begin{array}{l}\text { Keywords } \\
\text { (separated by “_") }\end{array}$ & \multicolumn{2}{|c|}{$\begin{array}{l}\text { Anatomy and Philosophy in Early Modern England - Commerce and } \\
\text { Merchants - Emotions, Passions, and Affections - - Empiricism - } \\
\text { Epicureanism - Habit - Hobbes, Thomas - Hume-Imagination (Emotions) - } \\
\text { Medicine and the Mind (cf. Psychology and Medicine) - Natural and } \\
\text { artificial - Reason and Experience - Scottish Moral Philosophy - } \\
\text { Skepticism - Sociability - Social Theories of Self/Mind - Society and } \\
\text { Sociability - Stoicism - Sydenham, Thomas - Willis, Thomas }\end{array}$} \\
\hline
\end{tabular}




\section{[AU1] 2 Mandeville, Bernard}

3 Mikko Tolonen', Mauro Simonazzi ${ }^{2}$ and

4 Andrea Branchi ${ }^{3}$

5 'Department of Digital Humanities, University of

- Helsinki, Helsinki, Finland

$7{ }^{2}$ Department of Philosophy, University of Milan,

- Milan, Italy

- ${ }^{3}$ IR Department, American University of Rome,

AU2 10 Rome, Italy

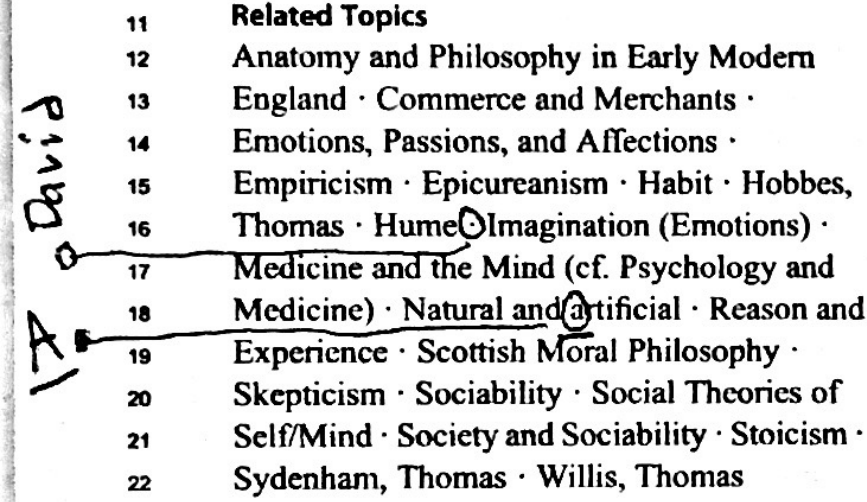

Publick Benefits/a little poem published in 1705 . $1 t$ started as and later expanded with long prose remarks 20 (1714) and other essays (1723). Mandeville 30 believed that human behavior, in its broad spec- 31 trum, could be traced back to the passions of pride 32 and vanity, their effects, and the efforts made to 33 control, hide, and gratify them. In contrast to the 34 common belief that personal virtue and civic 35 engagement are necessary to the well-being of 30 society, Mandeville scandalized his contempo- 37 raries by claiming that the prosperity of a large 36 commercial society was grounded upon the free 39 play of self-interested passions traditionally 40 denounced as vices.

Over almost 30 years of intellectual activity, Bernard Mandeville composed poems and female is dialogues, worked as a translator, wrote fables 4 and medical treatises, contributed to periodical 45 journals, produced philosophical essays and dia- 40 logues, and issued political pamphlets and tracts. 47 Yet, the shadow cast by the controversy over The 48 Fable of the Bees turned him in the public eye into 49 a cynical apologist of vices, as his work was 50 belittled as mere literary satire and an apology 51 for luxury and consumption. More recently, 52 because of his ideas on the unintended results of 53 cooperation among self-interested individuals, he 54 has become an ideological symbol as a forerunner 55 of economic liberalism?

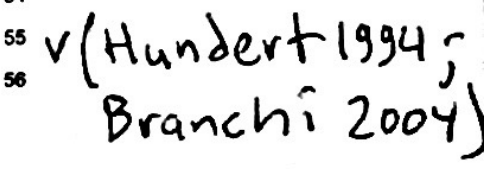


57 Mandeville in the Twenty-First Century:

so A Full-Size Philosopher

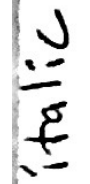

so One of the main reasons for the renewed interest

$\infty$ in Mandeville is the influence of F.A. Hayek and

or his thoughts about spontaneous order. Although

a there are good reasons not to think of Mandeville

- as a libertarian, much attention has been paid to

a the more radical elements of his thought. Only in

os the 1970s did his scholarship enter a new era, as

* Consideration was finally given to the vastness of

ㄱ 77 his interests and writings. Mandeville began to

a develop his theories in an unsystematic way, defy-

- ing the "public-spirit ideology" that characterized

if to early eighteenth-century political discourse. The

R $n$ author of the fable criticized those who located the

12 natural instinct of benevolence at the core of

n social organization. Satire and paradox represent

74 one side of Mandeville. What is more noteworthy,

75 however, is that in all his writings. he commits

r himself to a reconstruction of human nature that

$\pi$ conforms to the criteria of an empirical and expert-

no mental philosophy

- for vices and an empty paradoxical lampooning of

at current values are read today as a crucial step

02 toward the eighteenth-century ideal of the "sci-

w ene of man and an tempt

a to analyze passions consistently, - the mech-

os nisus and the genesis of commercial society

o including its historicaloigins and its incompeti-

87 bithecriticat an realistic calls for

* virtue and spirit. Recent scholarship

- acknowledges Mandeville's stature as an accom-

o phished philosopher whose influence on David

91 Hume and Adam Smith, and on Scottish and

22 European Enlightenment as a whole, still remains

93 to be reconstructed in depth.

$a \hat{\gamma}$

9 Dutch Background/Early WorkşPoems,

95 The Virgin Unmasked, and The Female

9 Tater

97 Bernard Mandeville was born in Rotterdam, the

s Netherlands, on November 15,1670 , to a family

of well-respected Dutch physicians, merchants,

100 and mid-level political officials. He studied at
University of Leiden, a cultural environment 101 hat was among the most advanced in Europe with 102 respect to Cartesianism and experimental philos- ices sophy. He graduated in philosophy in 1689 and in 104 medicine in 1691, specializing in digestive distr- 105 dens and their influence on psychological anti- 100 tunes. The Mandeville family's involvement in the so-called Costerman Riots in Rotterdam in 1690 is one possible reason for Bernard's emigra- 100 ton to the British Isles. ${ }^{V}$

Mandeville worked as a physician in England "1" from 1693 onward, treating nervous disorders in 112 connection with the lively Dutch community, as a in translator of medical treatises and of poetry, and as in an author of verse. In 1705 he published a poem is called The Grumbling Hive: or. Knaves Turn'd 11 Honest, which describes a large community of 117 bees, the mechanisms of its wealth, and the diss- 118 trows decline that is triggered as a result of an 119 attempt to moralize the lives of an opulent hive. 120 Describing the mechanisms of economic well- 121 being using the vocabulary of moralists, in Mandeville shows - not without irony - how the 123 effective implementation of a moral reform would ia inescapably lead to collective impoverishment. is Mandeville started his career as a prose winter 120 with a female identity, and in all his writings, he 127 maintained a keen interest in different aspects of women in society and on the "double standard" to applied to women and men in many areas of life: 130 education, social and economic status, and 131 the satisfaction of sexual desire. The Virgin 130 Unmask $d$, a series of ten dialogues between an 130 elderly maiden and her young niece, appeared in 134 1709, an exercise in the anatomy of human pas- 135 sons focusing on courtship rituals, conjugal life, 136 and the inequality of marital conditions. The 130 32 issues of the periodical The Female Tater 136 "by a Society of Ladies," which-Manderitte 130 wo te in 1710, turned Richard Steele's The Tatter and his enterprise of the Reformation of Manners 141 into a polemical target. This was an opportunity 10 for Mandeville to offer, albeit in a satirical and 14 polemical manner, the first set of arguments he $1 \mathrm{~m}$ developed in his later works about the standards of 145 female and male honor and their inequality, duel- 140 ling, the social function of pride and vanity, and a 147 naturalistic account of the origins of civil society. 148

line 86: $\checkmark$ in terms of human

passions (Castiglione 1986;

Jack 1989).

line 9B: $V$ (Robertson 2005; Tolonen 2013j Sinonazzi 2008 ; Branch 2004) 
Mandevillo published his first and only medical work, A Theatise of the Hypochondriack and Hysterick Passions, in 1711. Apparently, it was quite well received. In 1730 he published a second edition that expanded the work in length by about a third and with a slightly changed title (A Treatise of the Hypochondriack and Hysterick Diseases). The Treatise did not go unnoticed in the eighteenth century and circulated nmong English. Scottish, and Irish physicians. The dialogue form was not an original choice for a medical work, hut it was nonetheless an original decision to address patients rather than medical colleagues. Mandeville's method was to have the patient tell his or her own life story. The relevance of reporting disease history had been realized by Thomas Sydenham, who took his inspiration from Bacon's reflections on the importance of classification and natural history. This method was supposed to be applicable to any kind of disease. It consisted of following the evolution of the various cases, comparing them, and identifying their common elements so as to distinguish what was peculiar to the patient from what was specific to the disease. Mandeville followed in Sydenham's footsteps who, together with the physician Giorgio Baglivi, is quoted in the Treatise as one of his medical references.

Mandeville pays particular attention to the relationship between socioeconomic status and hypochondria. He claims that wealth is a predisposing factor because on the one hand it stimulates the fear of losing one's belongings and on the other hand it stimulates passions and desires that are difficult to satisfy. Fear and dissatisfaction are psychological causes of the loss of animal spirits. In this way, hypochondria is connected to passions, wishes, expectations, social conditions. the desire for social advancement, the fear of failure, and self-realization. It is a psychosomatic disease because the psychological dimension acts on the animal spirits, which are involved in digestion and can disturb the stomach. Mandeville, therefore, put mind and stomach in a strict relation through the mediation of animal spirits.

Mandeville stresses the importance of psychological factors in building rapport with the patient, and he also emphasizes that the patient must play 197 an active role in his or her therapy. Therapy here 100 does not include the use of drugs: it only requires 100 exercise. healthy food, and a sound relationship 200 between physician and patient, which is predi- 201 cated on listening and talking.

\section{The Fable of the Bees (1714)}

203

Mandeville republished his poem The Grumbling 204 Hive: or Knaves Turn'd Honest in 1714, still 200 anonymously, within a more articulated work 200 entitled The Fable of the Bees: or, Private Vices, 207 Publick Bencfits. It was preceded by a Preface and 200 followed by an Introduction. An Enquiry into the 200 Origin of Moral Virtue, and 22 Remarks in which 210 he developed the subjects dealt with in the poem. 211

The Introduction is particularly significant 212 because the theory of human nature is presented 213 in a synthetic but very effective form, according to 214 which man is "a compound of various Passions, 216 that all of them, as they are provoked and come 218 uppermost, geyem him by turns, whether he will 217 or not" (1t an antirationalistic 210 and deterministic conception, according to which 219 reason can only be instrumental and the bchavior 220 of individuals can be explained as responses to 221 stimuli that act on passions.

An Enquiry into the Origin of Moral Virtue 223 describes ethics as an invention of skillful politi- 224 cians who, levering pride and shame, produced 225 behavioral models and harmonized self-centered 220 passions that made them sociable. The origin of 227 society is grounded exclusively on human pas- 228 sions and their modifications, the fear of shame 220 and the desire to be praised. 230

Mandeville published Free Thoughts on Reli- 231 gion. the Church and National Happiness in 232 1720, and then he published a second expanded 233 edition in 1729. It was translated into French in 234 1722 and was condemned by the Sacred Congre. 235 gation of the Index in 1732. Free Thoughts deals 230 with theological issues such as free will and pre- 237 destination and the mysteries, rites, and ceremo- 230 nies in divine worship. Above all, however, 239 Mandeville analyzes the political function of the 240 church and accuses the clergy of having fomented 241 persecution and conflicts, favoring fanaticism and 242

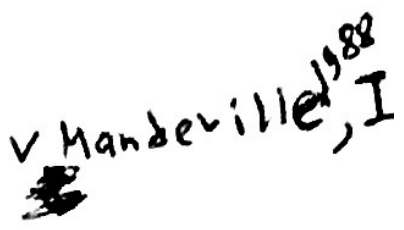

$$
\begin{aligned}
& \text { line 194: } V(\text { Simonazzi 2008; } \\
& \text { Cook 1999; Mckec 1995) }
\end{aligned}
$$




\section{The Fable of the Bees (1723) and Fame}

The 1720 s marked a watershed in Mandeville's philosophy. A few historical points might help to explain this. First, London and the whole of England were in the midst of a severe financial crisis caused by the 1720 South Sea Bubble. Second, in 1723 Mandeville published a second edition of The Fable of the Bees, in which he expanded on some Remarks and added an Index and a couple of essays: $A$ Search into the Nature of Society and An Essay on Charity and CharitySchools. He was made to appear in front of the grand jury of Middlesex when it declared The Fable of the Bees (1723) a public nuisance for its blasphemy and immorality. In response, he published a new edition in 1724 that included his reply to the grand jury, which he called $A$ Vindication of the Book. Finally, in 1725, his friend and protector Lord Macclesfield was found guilty of comuption in a trial that created a great scandal.

Mandeville targeted Lord Shaftesbury for criticism in A Search into the Nature of Society ("two Systems canno be more opposite than his Lordship's and mine," p. 324). He contrasted the relative conception of the pulchrum et honestum and the idea that society was not founded on sociability or virtue, but on competitive passions and on the need for social recognition.

$\checkmark$ Nevertheless, it was the Essay on Charity that prode the Fable of the Bees one of the most hotly discussed works of those years. The reason for the scandal was that Mandeville accused the Charity School Movement of hypocrisy, claiming that the schools were used for personal advantage by those who 288 promoted them. Furthermore, the children risked 289 being damaged because the school would have 200 created expectations that could not be realized. 291 This essay is often quoted because some scholars 292 believe it contains the most explicit formulation of 203 laissez-faire.

In 1724 Mandeville published another provoc- 295 ative piece called $A$ Modest Defence of Publick 296 Stews, in which he supports the public utility of 207 brothels and argues, on the basis of female anat- 200 omy and physiology, that chastity is an artificial 200 virtue. The following year he published $A n 300$ Enquiry into the Causes of the Frequent Execu- 301 tions at Tyburn, a collection of six anticles that had 302 appeared a few months earlier in the British Jour- 303 $\mathrm{nal}$, in which he proposed a reform of capital 304 punishment. The goal of the reform was to 305 achicve greater social stability with the least num- 306 ber of convictions.

307

\section{The Dialogues Between Horatio and 300 Cleomenes: Fable 1729}

Six years after the notorious second edition of the 310 Fable, Bemard Mandeville came out with a new 311 work entitled The Fable of the Bees: Part II. The 312 book is written as a dialogue between the two ${ }_{313}$ main characters, Horatio and Cleomenes. It is 314 not the case that this work is, in fact, a straightfor- 315 ward continuation of the Fable: it is rather a new 316 manifestation of a more mature Mandeville who, 317 especially in this later work, made a big impact on 318 the Enlightenment by directly influencing Hume, 319 Smith, Rousseau, and many others.

320

There is a clear change in Mandeville's think- 321 ing. He started out as a polemist, but later matured 322 into an original social theorist. This could not ${ }^{323}$ have happened without some revision of his 324 views. He developed a hypothesis explaining jus- 325 tice and politeness as decisive, artificial moral 326 institutions based on previous human conven- 327 tions. Later, he sought to detach himself from 320 Hobbism, which reduced all human actions to 329 self-love and self-preservation on the basis that 330 fear is the main element that civilizes men. 331 Mandeville's inclination in his later works was 332

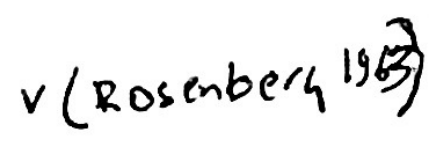
.

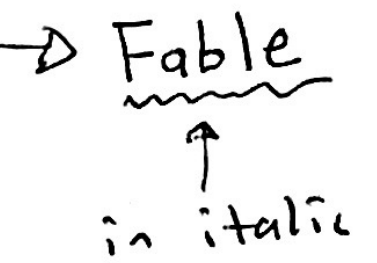

$$
\begin{aligned}
& \text { line 277: } \checkmark \text { Mandeville 1988, I, } \\
& \text { line 283: }-\vee \text { sapped attention }
\end{aligned}
$$


urture the passions, not to suffocate them. This is the same strategy that David Hume employs in his Treatise. The key move is to accept some other-regarding affection, parental affection for ther children being the prime example. It is noteworthy that Mandeville later characterized natural affection as a pure and durable passion. Without any selfish motives, parents can be said to love their children. The significance of this is that it facilitates discussion of fully natural virtues, such as kindness toward any living creatures, including animals als indicates is that we cannot simply ignore Mandeville by labelling his moral system utterly selfish, hedonist, or egoistic.

Mandeville's second move was to introduce a new concept: self-liking, which consists of two components. First, "nature has given" men "an instinct, by which every individual values itself above its real worth." Second, this natural instinct is aligned with "an apprehension" of the fact "that we do over-value ourselves," which "makes us so fond of the approbation, liking and assent of others; because they strengthen and confirm us in the good opinion we have of ourselves" (130). These definitions should be seen in the light of the French neo-Augustinian tradition and Pierre Nicole's writings in particular.

Being obliged to separate self-love and selfliking into their own spheres, we can show how to draw justice and politeness from corresponding passions. Justice guards our self-love. It has a lot to do with self-preservation, and it enables us to cultivate our self-interest. This is the sphere of life, limbs, and private property. At the same time, politeness is the moral institution that enables us to cultivate our self-liking. The idea is that passion itself is responsible for the corresponding moral institution. The geometrical simplicity of this is quite striking: now the idea is to cultivate the passions and not to curb them. The best instance of this is politeness and the popular idea in early modern Europe that one should hide one's pride. We all are naturally proud, the pride of others inhibits our pride, and therefore we should be proud without showing it to others. This creates a positive cycle of cultivating self-liking by developing different ways of pleasing others and not showing what one sis actually thinks of oneself. 302

This is the core of the scheme promoting the 303 conjectural development of civil society, which is built by deving new ways of cultivating self- 305 esteem. As Mandeville wrote, once laws have 306 been written down, everything else follows 307 apace. What is important here is the idea that laws (like any other coined rule) follow a previous 300 convention. This is the logic of civil society, the 300 basis on which Hume was later to argue that 301 government was based on opinion. Mandeville is 302 famous today as a laissez-faire theorist, but his impact lies in his understanding of the relationship between passions and the gradual development of ses structures that hold up civil society in spite of human frailty. $V$

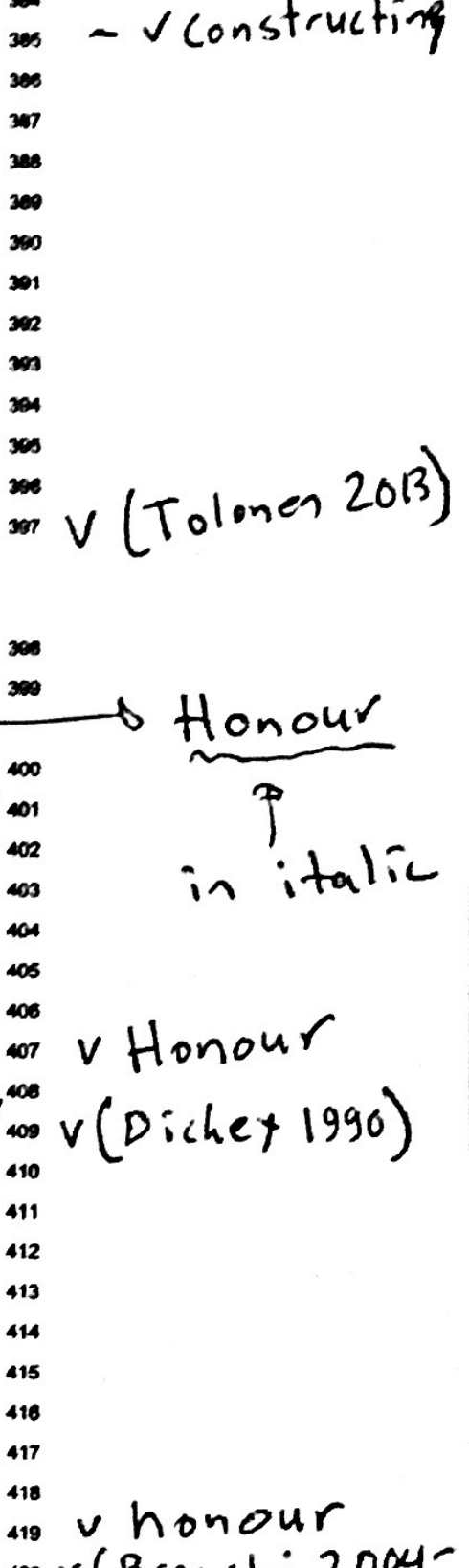

\section{The Dialogues Between Horatio and Cleomenes: fonor 1732}

Mandeville's last research book was the Enquiry 100 into the Origin of Honour and the Usefulness of 401 Christianity in War (1732), which further 402 develops his analysis of self-liking, its role in the 203 evolutionary account of human institutions, and the way in which political power exploited ideal- 405 ized social models of self-promotion.

Honor as a general principle refers to the sys- 400 tems of unwritten values of pride and shame that 100 humans have developed based of self-liking. 409 In contrast to proponents of the Deist tradition, 410 Mandeville stresses the impossibility of rational- 411 izing the true message of the gospel and reconcil- 412 ing it with social utility. Religion, which 413 originated in men's fear of an invisible cause, 414 has been distorted and "politically used" as a 415 formidable tool of social control. Virtue and 416 honor are of the same origin, namely, our hyper- 417 sensitivity to other people's judgments. Yet, in 418 that is it less demanding, honer has been by far 419 more useful to society.

Polite, modern manners are simply the last 421 stage in the history of pride. The traditional virtues 42 of male and female bonor, courage, and chastity 423 are far from being original, natural tendencies. 424

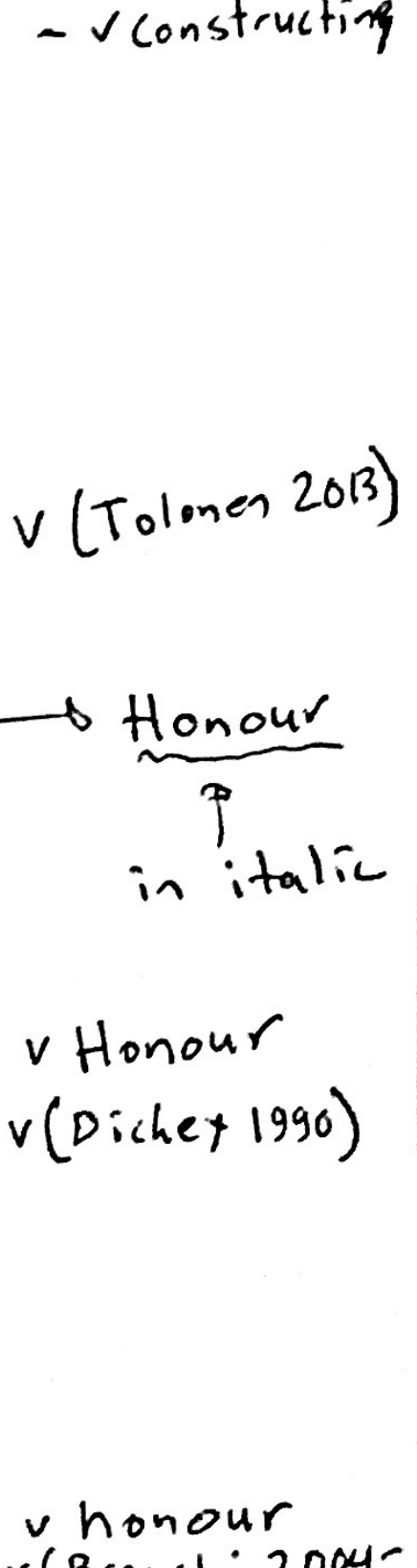
They are rather the result of education and 425 $\checkmark$ constructing $\checkmark$ honour

$$
\text { line 368: } \checkmark \text { Mandeville 1988, I, }
$$


426 Socialization, an exemplary expression of an arti427 ficial order growing out of a natural disposition of

passions. Men fight duels not because they love virtue or justice but because they fear shame more than death. The passion of self-liking is a much stronger and more widely diffused and practiced motivation for "virtuous" behavior than any ideal of virtue itself. In distinguishing the form of honorable conduct that characterized the moral history of postmedieval Europe, Mandeville was able to identify the new social conventions by which citizens of commercial societies could sublimate the primary demands of self-liking in materially productive and psychologically rewarding ways.

\section{Mandeville's Influence}

Bemard Mandeville made an impact on the Enlightenment and beyond. First, it should not be forgotten that his was a versatile talent. His main occupation was that of a medical doctor, who also published poetryets, He also translated medical works. His own main medical opus was still being cited in the nineteenth century. Second, Mandeville was a notorious polemist who, as a provocative and somewhat misunderstood character, was able to create a hugely influential discussion about human nature and luxury. The Fable of the Bees is in many ways the book of the Enlightenment. Third, Mandeville evolved in his career as a social theorist, proving to be an original thinker. His fate was such, however, that his genius has not really been appreciated. He is often still dismissed as an author on account of his polemical side, even though David Hume and Adam Smith, for example, developed their ideas about the development of civil society precisely on his premises. Mandeville published his last work as a response to George Berkeley (Letter to Dion, 1732). His message was that his intellectual integrity should be taken seriously.

Branchi A (2004) Introduzione a Mandeville. Laterza, 466 Roma-Bari

Carrive P (1980) Bernard Mandeville: passions, vices, 468 vertus. Vrin, Paris

Castiglione D (1986) Considering things minutely: reflec- 470 tions on Mandeville and the 18th century science of 471 man. Hist Polit Thought 7:463-488

472

Cook HJ (1999) Bernard Mandeville and the therapy of 473 "the clever politician". J Hist Ideas 60:101-124 474

Decker R (1992) "Private vices, public virtues" revisited: 475 the Dutch background of Bernard Mandeville. 478 Translated by G. T. Moran. Hist Eur Ideas 14:481-498 477

Dickey L (1990) Pride, hypocrisy, and civility in 478 Mandeville's social and historical theory. Crit Rev 479 4:387-431

Goldsmith MM (2001) Private vices, public benefits. 481 Bernard Mandeville's social and political thought. 462 Revised edn. Cybereditions $\vee$

Hayck FA (1966) Dr. Bernard Mandeville', lecture on 484 a master mind series. Proc $\mathrm{Br}$ Acad 52:139. Oxford 485 University Press V

Horne TA (1978) The social thought of Bernard 487 Mandeville. Virtue and commerce in early eighteenth- 488 century England. Columbia University Press, 469 New York

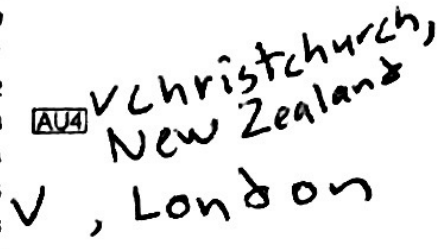

Hundert EJ (1994) Enlightenment's fable. Bernard 491 Mandeville and the discovery of society. Cambridge 492 University Press, Cambridge

Jack M (1989) Comuption and progress. The eighteenth century debate. AMS, New York

McKee F (1995) Honeyed words: Bernard Mandeville and 496 medical discourse. In: Porter R (ed) Medicine in the 497 enlightenment. Rodopi, Amsterdam, pp 223-254 498

Monro H (1975) The ambivalence of Bernard Mandeville. 499 Oxford University Press, Oxford

500

Peltonen M (2003) Politeness, duelling and honour in 501 Bemard Mandeville. In: The duel in early modem 502 England: civility, politeness and honour. Cambridge 503 University Press, Cambridge, pp 263-302 504

Primer I (ed) (1975) Mandeville studies. New explorations 505 in the art and thought of Dr. Bernard Mandeville. 506 Martinus Nijhoff, Hague

507

Robertson J (2005) Hume after Bayle and Mandeville. In: 508 The case for the enlightenment Scotland and Naples, 509 1680-1760. Cambridge University Press, Cambridge, 510 pp 256-324

511

Rosenberg N (1963) Mandeville and Laissez-Faire. J Hist 512 Ideas 24:183-196

Schneider L (1987) Paradox and society. The work of 514 Bernard Mandeville (ed: Weinstein J) New Brunswick 515

\section{$\checkmark$ Transaction Books}

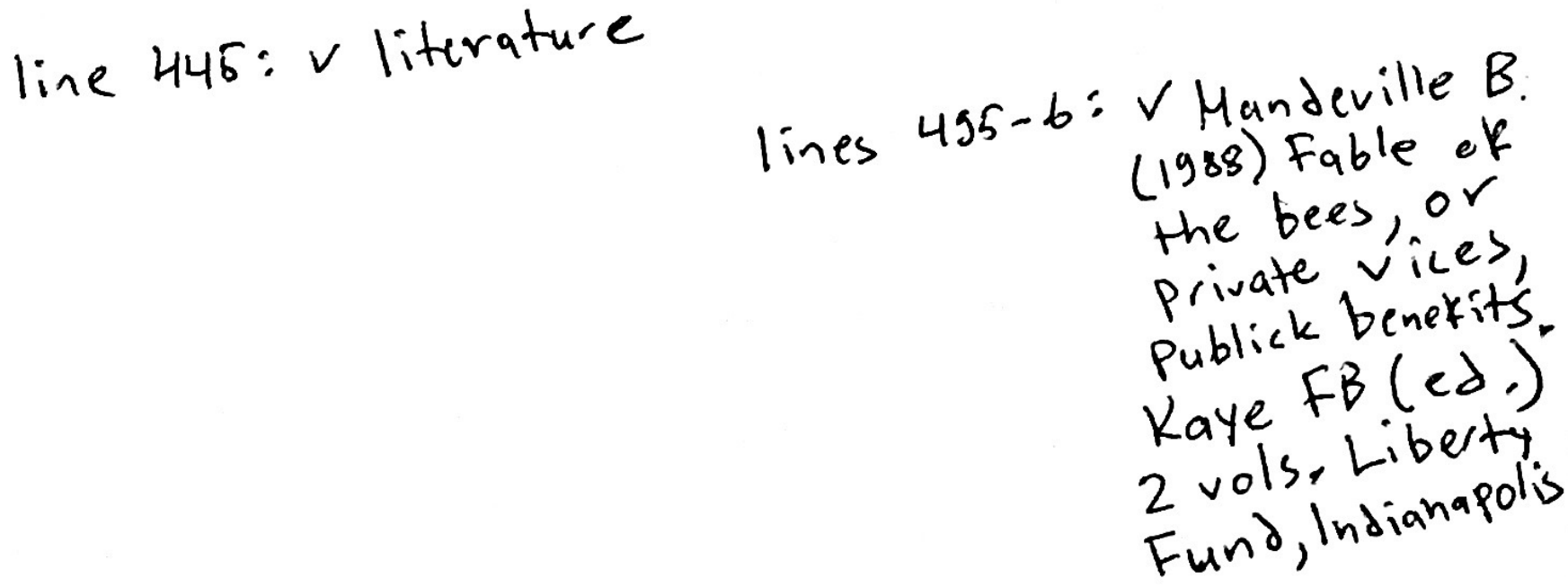


510 Simonazzi M (2008) Le favole della filosofia. Saggio su Bernard Mandeville. FrancoAngeli, Milano

518 Tolonen M (2013) Mandeville and Hume: anatomists of
Vertury R (2016) The Dulch background of Bernats 50 Mandeville's thought escaping the Procrustean bed of 501

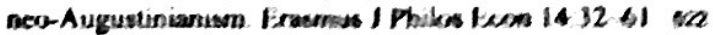




\section{Author Queries}

Chapter No.: 498-1 340010_0_En

\begin{tabular}{|c|c|c|}
\hline Query Refs. & Details Required & Author's response \\
\hline AUI & $\begin{array}{l}\text { Chapter title has been set as per Job sheet. Please check } \\
\text { if okay. }\end{array}$ & OK \\
\hline AU2 & $\begin{array}{l}\text { Please be aware that your name and affiliation and if } \\
\text { applicable those of you co-author( }(\mathbf{s}) \text { will be published as } \\
\text { presented in this proof. If you want to make any } \\
\text { changes, please correct the details now. Note that } \\
\text { corrections after publication will no longer be possible. }\end{array}$ & All ok \\
\hline AU3 & Please cite all the references in the text. & added \\
\hline AU4 & $\begin{array}{l}\text { Please provide publisher location for Goldsmith (2001), } \\
\text { Hayck (1966). }\end{array}$ & $O K$ \\
\hline AUS & Please provide publisher name for Schneider (1987). & OK \\
\hline
\end{tabular}

Note:

If you are using material from other works please make sure that you have obtained the necessary permission from the copyright holders and that references to the original publications are included. 